\title{
Reassignment of Pagurus lepidochirus (Doflein) to Nematopagurus A. Milne Edwards \& Bouvier (Decapoda: Anomura: Paguridae) and its redescription
}

Tomoyuki Komai and Patsy A. McLaughlin

Abstract.-One of the three syntypes of Pagurus lepidochirus (Doflein, 1902) was reexamined. This female syntype was found to possess paired first pleopods modified as gonopods, broadly separated ocular acicles and subequal chelipeds, suggesting reassignment of this species to either the genus Nematopagurus A. Milne-Edwards \& Bouvier, 1892, or to Ceratopagurus Yokoya, 1933. Study of supplemental material has revealed the presence of a long, filamentous right sexual tube in males, requiring reassignment of this species to Nematopagurus. Further comparisons have shown that Doflein's taxon is identical with a species reported from Japanese waters as $N$. squamichelis Alcock, 1905. Nematopagurus lepidochirus is redescribed and illustrated in detail on the basis of the lectotype, herein selected, and supplemental material. Differences between this species and other closely allied taxa, including the true $N$. squamichelis, are discussed.

\section{Introduction}

Pagurus lepidochirus (Doflein, 1902) was described by Doflein (as Eupagurus) from three specimens collected in Sagami Bay, Japan, but no additional specimens of this species have been reported since. It was included by Miyake (1978, 1982, 1991, 1999), in the fauna of Sagami Bay on the basis of Doflein's (1902) original description, and adjudged by Miyake $(1978,1982)$ to be most closely related to
P. exiguus (Melin, 1939). However, after examining Melin's (1939) syntypes of the latter species, McLaughlin \& Sandberg (1995: 370, fig. 1) pointed out that Melin (1939) had erred in implying that the chelipeds of $P$. exiguus were provided with squamiform scales. Doflein's (1902) species bears no resemblance to $P$. exiguus. Recently, one of us (TK) examined one of the three syntypes of Eupagurus lepidochirus, a female, deposited in the collection of the Zoologische Staatssammlung Munich, Germany. The other two syntypes could not be located. This female syntype proved to have paired first pleopods modified as gonopods, and other characters suggesting the reassignment of the species either to the genus Nematopagurus A. MilneEdwards \& Bouvier, 1892, or to Ceratopagurus Yokoya, 1933.

Examination of supplemental material clearly identifible as Doflein's (1902) taxon has demonstrated the presence, in males, of a long, filamentous right sexual tube. Consequently, Pagurus lepidochirus must be reassigned to the genus Nematopagurus, as males of Ceratopagurus lack sexual tubes (Yokoya, 1933: 93). Further study has shown that $N$. lepidochirus is identical to the species identified_in Japanese waters as Nematopagurus squamichelis Alcock, 1905 (Miyake, 1978, 1982, 1991, 1999; Miyake \& Imafuku, 1980; Baba, 1986). In the present account, Nematopagurus lepidochirus is redescribed and illus- 
trated in detail on the basis of the lectotype (herein designated) and supplemental material. A comparison with closely allied species, including the true $N$. squamichelis, is made.

Materials for this study are deposited in the following institutions: Natural History Museum and Institute, Chiba (CBM); Osaka Museum of Natural History, Osaka (OMNH); Muséum national d'Histoire naturelle, Paris (MNHN); Naturhistorisches Forschungsinstitut Museum für Naturkunde zu Berlin (ZMB); Forschunginstitut Senckenberg, Frankfurt am Main (SMF); and Zoologische Staatssammulung München (ZSM). Shield length (sl), as measured from the midpoint of the rostral lobe to the midpoint of the posterior margin of the shield, indicates specimen size. General terminology used in the description follows McLaughlin (1974), with exception of the fourth pereopod (see McLaughlin, 1997) and gill structure (see McLaughlin \& de Saint Laurent, 1998). The drawings were made with the aid of a drawing tube mounted on Leica MZ-8 stereomicroscope.

\section{Taxonomy}

\section{Nematopagurus lepidochirus}

(Doflein, 1902), new combination

Figs. 1-4

Eupagurus lepidochirus Doflein, 1902: 623 (type locality: Sagami Bay); Alcock, 1905: 177 (list); Terao, 1913: 370.

Pagurus lepidochirus - Gordan, 1956: 331 (bibliography); Miyake, 1978: 81 (key), 110; 1982: 198 (list), 227 (key); 1991: 198 (list), 227 (key); 1999: 198 (list), 227 (key).

Nematopagurus squamichelis - Miyake, 1978: 129 (key); Miyake \& Imafuku, 1980: 63; Miyake, 1982: 198 (list), 230 (key); Baba, 1986: 201, 303, unnumbered fig. on page 200 (top); Miyake, 1991: 198 (list), 230 (key); 1999: 198 (list), 230 (key); Komai, 1999: 28. Not Nematopagurus squamichelis Alcock, 1905.
Material examined.-Lectotype (herein selected). Sagami Bay, 1901, female (sl $7.3 \mathrm{~mm}$ ), ZSM 292/1.

Other material. Kii Peninsula: off Mie Prefecture, 100-200 m, I.1977, coll. S. Habu, 1 male (sl $6.9 \mathrm{~mm}$ ), reported by Miyake \& Imafuku (1980) as Nematopagurus squamichelis, OMNH-Ar 1979. Tosa Bay: 1961-1963, coll. K. Sakai, 1 male (sl $6.4 \mathrm{~mm}$ ), SMF 11187; 250-300 m, 24.III.1963, coll. K. Sakai, 1 male $(\mathrm{sl} 7.4 \mathrm{~mm}), 2$ females, one with rhizocephalan (sl 6.5, $7.3 \mathrm{~mm}$ ), 1 ovig. female $(\mathrm{sl} 7.4 \mathrm{~mm}$ ), SMF $11185 ; 250 \mathrm{~m}$, IV.1968, coll. K. Sakai, 1 male (sl $6.4 \mathrm{~mm}$ ), 1 ovig. female (sl $5.1 \mathrm{~mm}$ ), SMF 11188; off Tosa, 190 m, 10.VIII.1991, RV Toyohatamaru, beam trawl, coll. K. Sasaki, 1 male (sl $8.2 \mathrm{~mm}$ ), CBM-ZC $185 ; 33^{\circ} 16.02^{\prime} \mathrm{N}$, $133^{\circ} 40.02$ 'E, $189-190 \mathrm{~m}, 9 . \mathrm{IV} .1993$, RV "Toyohata-maru", beam trawl, coll. K. Sasaki, 1 male (sl $6.0 \mathrm{~mm}$ ), CBM-ZC 3842; $33^{\circ} 17.12^{\prime} \mathrm{N}, 133^{\circ} 40.02^{\prime} \mathrm{E}, 150-154 \mathrm{~m}$, 5.III.1993, RV "Toyohata-maru", beam trawl, coll. K. Sasaki, 1 female (sl 6.7 $\mathrm{mm})$, CBM-ZC $3856 ; 33^{\circ} 17.12^{\prime} \mathrm{N}$, $133^{\circ} 40.23^{\prime} \mathrm{E}, 150-152 \mathrm{~m}$, 4.II.1993, RV "Toyohata-maru", beam trawl, coll. K. Sasaki, 1 male (sl $6.7 \mathrm{~mm}$ ), 1 female (sl 7.3 $\mathrm{mm}$ ), CBM-ZC 3943; off Ashizuri-misaki, 200-300 m, 26.XI.1996, commercial trawler, coll. T. Komai, 2 males (sl 6.1, 6.2 $\mathrm{mm}$ ), 1 female (sl $5.5 \mathrm{~mm}$ ), CBM-ZC 3266 . East China Sea: RV "Yoko-maru", stn A175, SW of Goto Islands, $31^{\circ} 39.7^{\prime} \mathrm{N}$, $128^{\circ} 15.6^{\prime} \mathrm{E}, 176 \mathrm{~m}, 7$.VIII.1996, otter trawl, coll. T. Kosuge, 1 female (sl 7.7 $\mathrm{mm}$ ), CBM-ZC 2960; stn E300-5, W of Tokara Islands, $28^{\circ} 57.00^{\prime} \mathrm{N}, 127^{\circ} 06.20^{\prime} \mathrm{E}$, $307 \mathrm{~m}, 24 . X .1997$, otter trawl, coll. T. Kosuge, 1 male (sl $5.5 \mathrm{~mm}$ ), CBM-ZC 5399 .

Redescription.-Shield (Fig. 1A) slightly longer than broad to slightly broader than long; anterolateral margins sloping or slightly terraced; anterior margin between rostrum and lateral projec- 

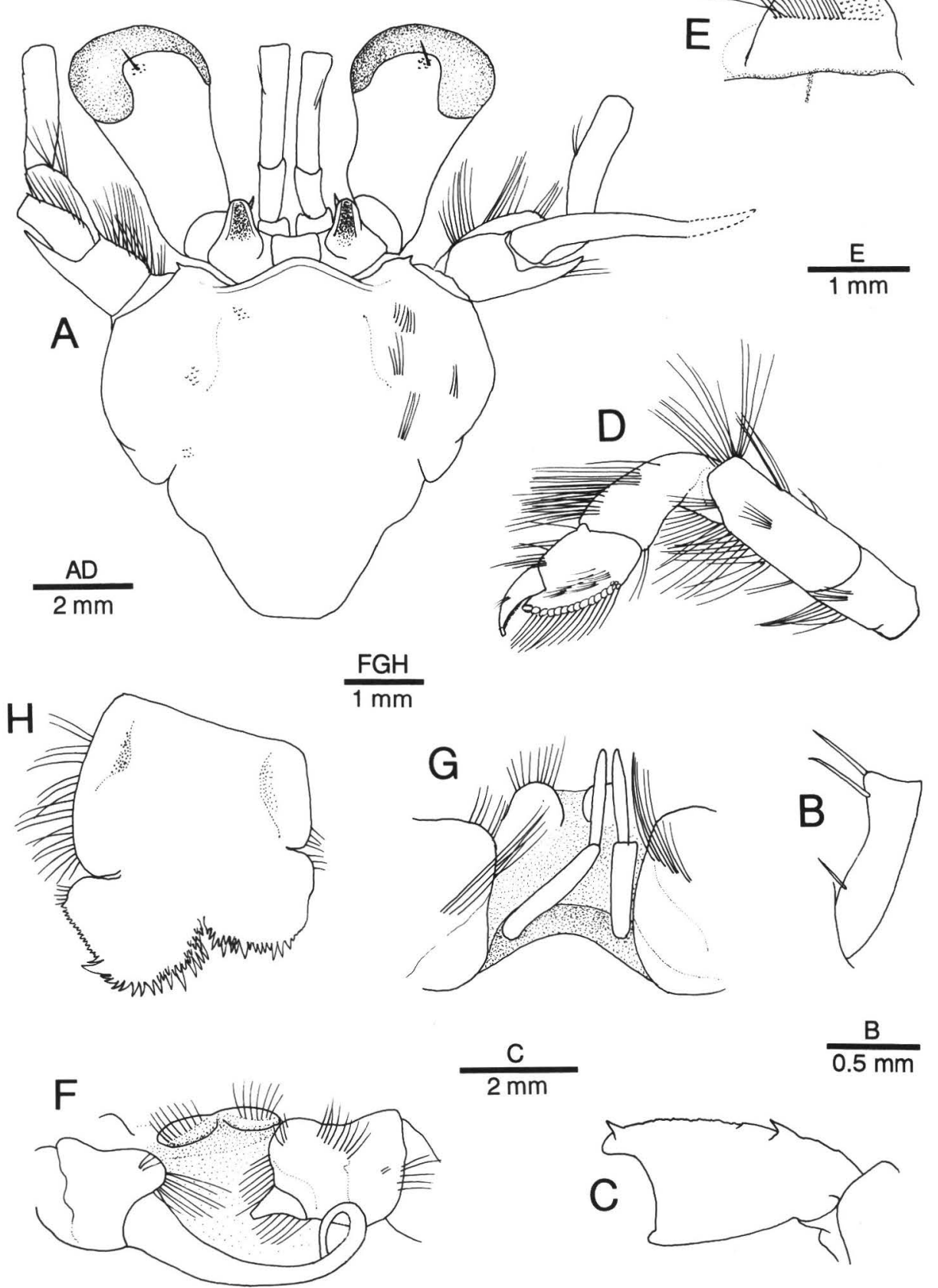

Fig. 1. Nematopagurus lepidochirus (Doflein, 1902), new combination. A, D, E, G, H, lectotype, female (sl 7.3 mm) from Sagami Bay, ZSM 292/1; B, C, female (sl 5.5 mm) from Tosa Bay, CBMZC 3266; F, male (sl $6.2 \mathrm{~mm}$ ), same lot. A, shield and cephalic appendages, dorsal, antennular flagella missing, setae partially omitted; B, endopod of left maxillule, lateral; C, carpus of right second pereopod, mesial, setae omitted; D, left fourth pereopod, lateral; $\mathrm{E}$, anterior lobe of sixth thoracic sternite, ventral, setae partially missing; F, coxae of fifth pereopods, showing sexual tubes, ventral; $\mathrm{G}$, first pleopods, ventral; $\mathrm{H}$, telson, dorsal. 
tions sinuous, forming blunt angle mesial to spine on lateral projection; posterior margin truncate or slightly concave; dorsal surface with some paired tufts of setae. Rostrum broadly rounded or broadly subtriangular, reaching level of lateral projections. Lateral projections prominent, subquadrate, each with laterally directed submarginal spine.

Ocular peduncles (Fig. 1A) short, 0.75-0.80 length of shield, somewhat flattened dorsoventrally; surfaces each with dorsomedian tuft of stiff setae at base of cornea and few tufts of very short setae dorsally and mesially; corneas strongly dilated, corneal diameter about $0.70-0.80$ of ocular peduncle length. Ocular acicles small, terminating bluntly, with deeply concave dorsal surface and small submarginal spine.

Antennular peduncles (Fig. 1A) moderately short, exceeding distal margins of corneas by $0.10-0.25$ length of ultimate segment. Ultimate segment with longitudinal row of tufts of stiff setae on dorsal surface. Penultimate segment with few short setae. Basal segment with short setae dorsally and distally, prominent spine on lateral face of statocyst lobe.

Antennal peduncles (Fig. 1A) moderately short, reaching to or overreaching distal margins of corneas by $0.10-0.20$ length of fifth segment. Fifth segment with few short setae dorsally and distally. Fourth segment with long stiff setae, especially on mesial surface. Third segment with small spine at ventrodistal angle completely concealed by long stiff setae. Second segment with dorsolateral distal angle produced, reaching to or overreaching midlength of fourth segment, terminating in simple or bifid spine; lateral and mesial faces with long stiff setae; dorsomesial distal angle with small spine. First segment produced ventrolaterally as flattened subacute lobe; lateral face without spine. Antennal acicle moderately long, overreaching midlength of fifth peduncular segment; slightly arcu- ate, terminating in acute spine; mesial margin with numerous tufts of long stiff setae. Antennal flagella long, overreaching tip of right cheliped; every article with few very short or short setae, at least in proximal half.

Endopod of maxillule (Fig. 1B) with internal lobe well developed, triangular, bearing 2 setae ( 1 apical and 1 subapical); external lobe weakly produced as triangular projection with acutely pointed apex. Third maxilliped with ischium bearing well developed crista dentata composed of fine row of small corneous teeth and 1 strong accessory tooth.

Chelipeds (Figs. 2, 3) subequal in length; right somewhat stronger than left, but sometimes shorter; stiff, iridescent setae arising from transverse scutes or ridges. Right chela (Figs. 2A, B, 3A, B) about 2.40 times longer than broad. Dactylus slightly shorter than palm; cutting edge with elongate, fused pair of strong calcareous teeth separated from single subtriangular calcareous tooth by 1-2 smaller calcareous teeth, with row of small corneous teeth in distal third, terminating in small corneous claw and slightly overlapped by fixed finger; proximal half of dorsal surface with few to several low, short, transverse scutes mesially and extending onto rounded, unarmed dorsomesial margin, each scute with marginal row of short stiff setae, tufts of somewhat longer setae on distal part and area adjacent to cutting edge; mesial face with short vertical ridges or low protuberances accompanied by longer setae; ventral surface with 2 longitudinal rows of tufts of long setae. Palm 0.75-0.85 length of carpus; dorsomesial margin creased by series of short, transverse scutes, each frequently with small spine and fringe of stiff setae; dorsal surface weakly convex, with 9-13 irregular transverse rows of short scutes, each with marginal row of short stiff setae; dorsolateral margin creased by series of short transverse scutes, each sometimes with small spine, 

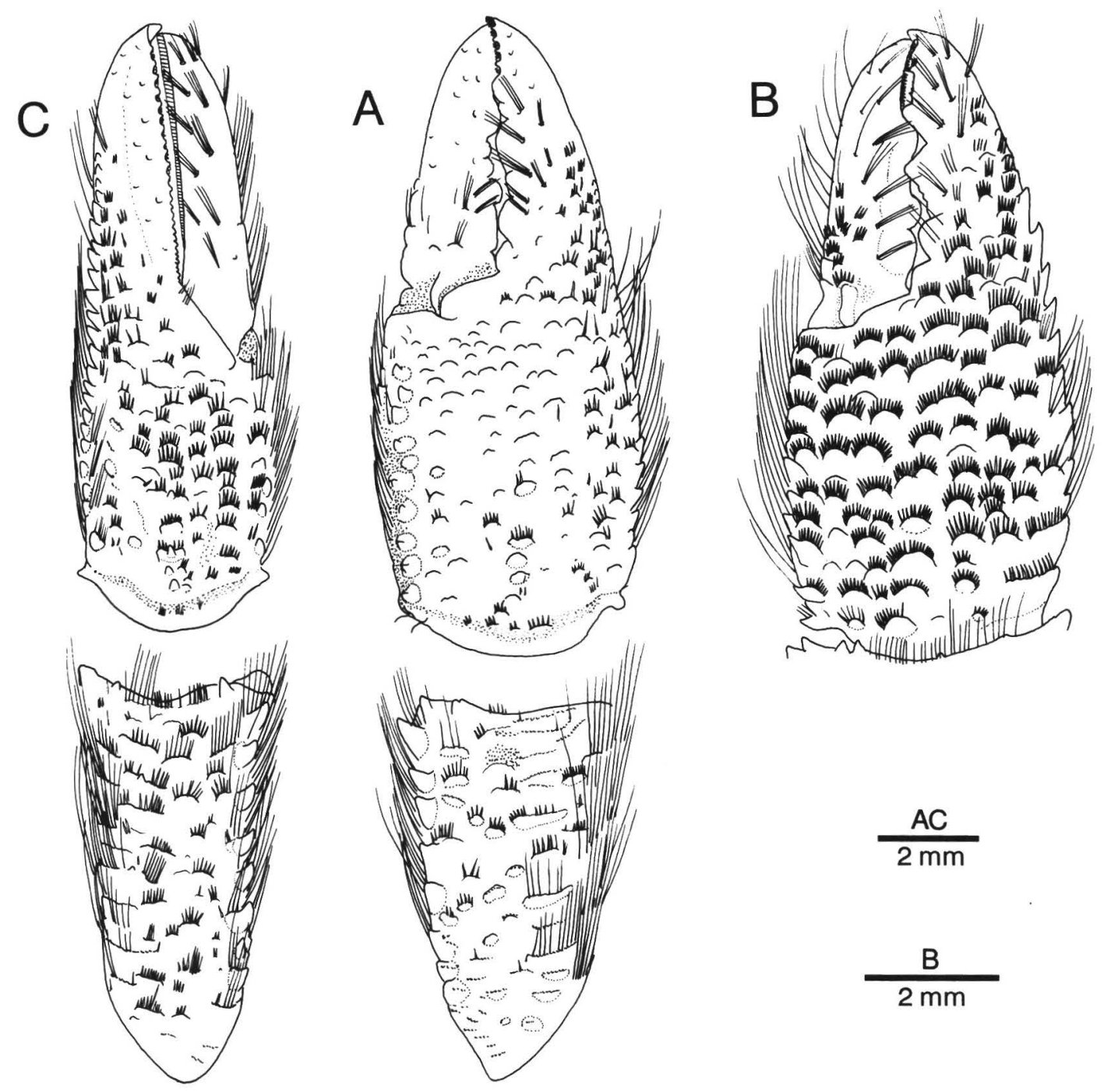

Fig. 2. Nematopagurus lepidochirus (Doflein, 1902), new combination. A, C, lectotype, female (sl $7.3 \mathrm{~mm}$ ) from Sagami Bay, ZSM 292/1; C, female (sl $5.5 \mathrm{~mm}$ ) from Tosa Bay, CBM-ZC 3266. Chelipeds. A, right chela and carpus, dorsal, setae partially missing; B, chela, dorsal; C, left chela and carpus, dorsal, setae partially missing.

dorsolateral margin of fixed finger delimited with row of small spines or spinulose tubercles at least in proximal half (considerably reduced in larger specimens); mesial face dorsally with short scutes and low, obliquely vertical ridges provided with longer stiff setae, and ventrally with few low protuberances accompanied by tufts of long setae; proximal $0.60-0.80$ of dorsal surface of fixed finger with irregu- lar transverse rows of short scutes provided with marginal short stiff setae; distal $0.40-0.20$ of dorsal surface of fixed finger nearly smooth, with only scattered tufts of setae; cutting edge with 3 strong calcareous teeth in proximal $0.70-0.80$ and row of small calcareous teeth interspersed with corneous teeth in distal $0.20-0.30$, terminating in small corneous claw; lateral face of palm and fixed finger 


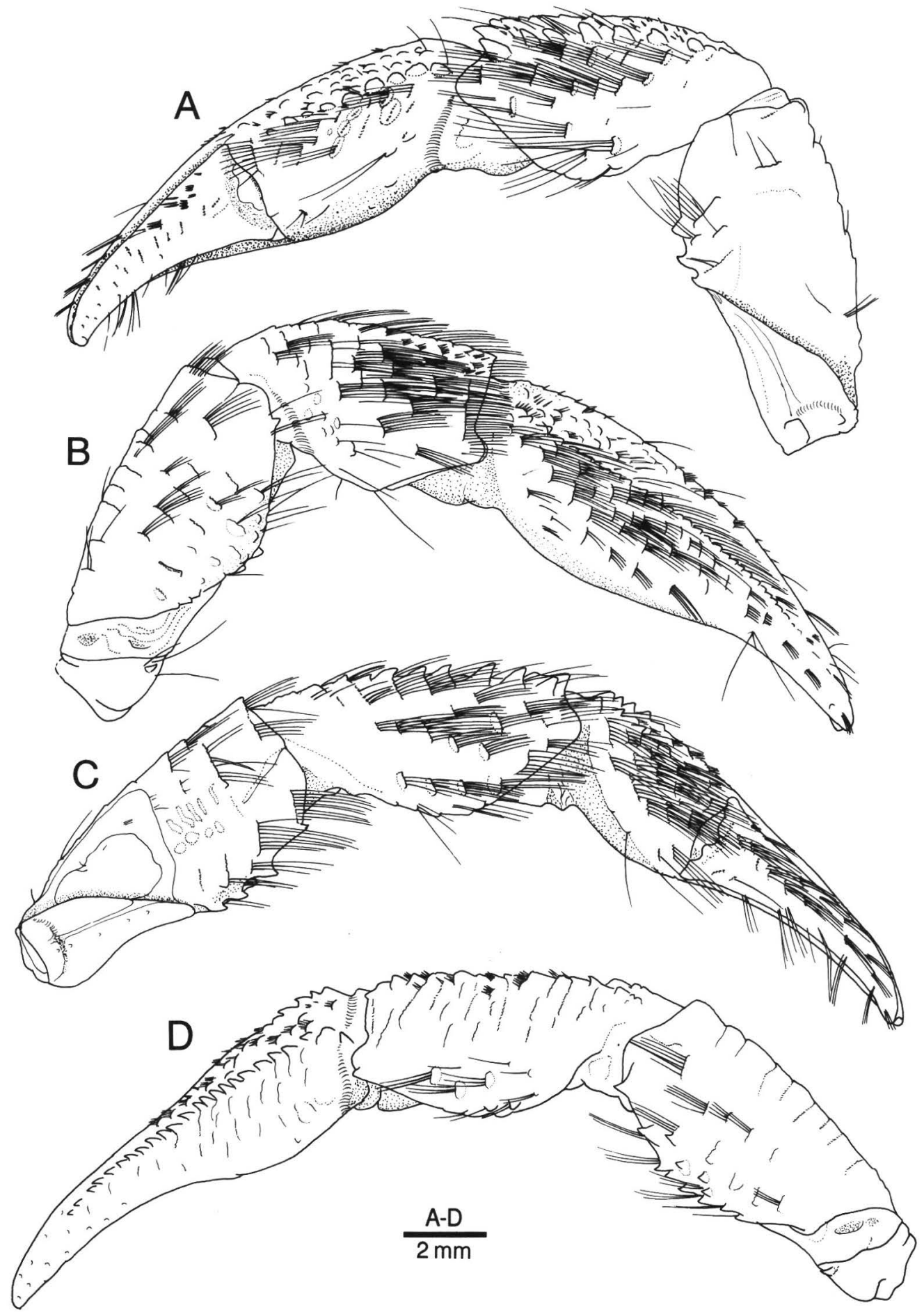

Fig. 3. Nematopagurus lepidochirus (Doflein, 1902), new combination. Lectotype, female (sl 7.3 $\mathrm{mm}$ ) from Sagami Bay, ZSM 292/1. Chelipeds. A, right cheliped, mesial, setae partially missing; B, same, lateral; C, left cheliped, mesial, setae partially missing; D, same, lateral, setae partially omitted. 
with short vertical (transverse) ridges or scutes (becoming fewer ventrally and distally) each provided with marginal short to long stiff setae; ventral surfaces of palm and fixed finger with scattered tufts of moderate to long setae. Carpus slightly shorter than merus, becoming noticeably broader distally; dorsodistal margin with row of short stiff setae; dorsomesial margin with row of moderately strong spines; dorsal surface medially with shallow depression somewhat proximal to dorsodistal margin, and with irregular transverse rows, each consisting of 3-6 scutes, extending onto dorsal half of lateral face, and provided marginally with short stiff setae; dorsolateral margin not delimited; lateral and mesial faces with short transverse ridges and moderate to long setae; ventral surface with few low protuberances and tufts of short to long setae. Merus with short transverse ridges, each provided with row of stiff setae on distal half of dorsal surface; proximal half of dorsal surface with few tufts of setae; lateral and mesial faces each with transverse ridges and long stiff setae; ventrolateral margin with $2-3$ small spines and $2-3$ blunt tubercles; ventromesial margin with $3-5$ small spines; ventral surface with few tubercles or spines and tufts of moderately long setae. Ischium with few setae; 1 spine at ventrolateral distal angle.

Left cheliped (Figs. 2C, 3C, D) moderately slender. Dactylus 1.50-1.80 times longer than palm; cutting edge with row of corneous teeth, terminating in small corneous claw and slightly overlapped by fixed finger; dorsal surface with $2-3$ rows of sparse tufts of setae, few to several short marginally setiferous scutes proximally, extending onto mesial face dorsally; dorsomesial margin not delimited; mesial and ventral faces also with numerous long setae. Palm 0.60-0.75 length of carpus; dorsomesial margin not clearly delimited, but with 3-4 small spines proximally; dorsal surface, like that of right, with 7-11 irregular, transverse rows of short scutes, extending onto lateral and mesial faces, each provided with marginal row of short stiff setae; scutes on midline sometimes each with small spine; dorsolateral margin (including fixed finger) delimited with row of small spines extending to distal 0.80 of fixed finger; dorsal surface of fixed finger with several transverse rows of short scutes in proximal $0.70-0.80$, each with marginal fringe of short stiff setae, distal $0.20-0.30$ with scattered tufts of setae; ventral surfaces of palm and fixed finger with short transverse rows of long stiff setae; cutting edge of fixed finger with row of small calcareous teeth interspersed with corneous teeth. Carpus approximately equal to slightly longer than merus; dorsodistal margin with row of short to moderately long stiff setae; dorsomesial margin with row of moderately strong spines, partially obscured by long stiff setae, dorsolateral margin not delimited; dorsal surface with irregular, transverse rows of short, marginally setiferous scutes extending onto lateral face; mesial and ventral surfaces with short transverse ridges each bearing long stiff setae. Merus with few short, transverse ridges and tufts of moderately long setae on distal half of dorsal surface; proximal half of dorsal surface with few tufts of shorter setae; dorsodistal margin with row of moderately long stiff setae; lateral and mesial faces with short, transverse ridges bearing row of long setae; ventral surface with few small spines laterally and tufts of short stiff setae; ventrolateral margin with $3-5$ spines, ventromesial margin with 4-6 spines. Ischium with few tufts of setae and spine at ventrolateral distal angle.

Ambulatory pereopods (Fig. 4A-D) moderately slender; right second pereopod overreaching tip of right cheliped by $0.50-0.70$ length of dactylus. Dactyli very slender, 1.30-1.50 times as long as propodi in second, 1.50-1.90 times as long in third; in lateral view, nearly straight to 
curved ventrally (right dactyli more strongly curved than left); in dorsal view, strongly twisted in distal $0.30-0.50$; each terminating in small corneous claw; dorsal surfaces each with single row of long spiniform setae and irregular rows of shorter spiniform setae or corneous spinules in proximal half; lateral faces each with trace of median sulcus; mesial faces each dorsally with row of small corneous spines becoming longer distally; ventral surfaces each with 6-14 small to long corneous spines increasing in size distally. Propodi distinctly longer than carpi; dorsal surfaces each with row of short, transverse ridges extending onto lateral faces and set with short stiff setae; lateral and mesial faces with scattered setae; ventral surfaces with widelyspaced sparse tufts of setae, 1-2 small corneous spines at ventrodistal angle. Carpi shorter than meri; dorsal surfaces each with 2 spines in second (1 dorsodistal and 1 subproximal) (Fig. 1C) and only 1 spine at dorsodistal angle in third, and transverse rows of tufts of stiff setae; lateral faces each with several short to moderately long, transverse rows of stiff setae; mesial and ventral surfaces each with few scattered tufts of stiff setae. Meri each with row of transverse ridges and stiff setae on dorsal surfaces; lateral and mesial faces with few tufts of setae; ventral surfaces weakly protuberant, with row of spaced tufts of stiff setae. Ischia each with setae dorsally and ventrally.

Fourth pereopods (Fig. 1D) with numerous stiff setae on dorsal surfaces of propodi, carpi and meri; dactyli without preungual process; propodal rasp composed of single row of corneous scales.

Anterior lobe of sixth thoracic sternite (Fig. 1E) subsemicircular, with long setae on anterior surface.

Males with well-developed, elongate, filiform sexual tube on coxa of right fifth pereopod (Fig. 1F); left coxa with very short sexual tube. Females with paired first pleopods (Fig. 1G) ; distal segment shorter than proximal segment.

Telson (Fig. 1H) with distinct transverse indentations; posterior lobes slightly asymmetrical, subsemicircular to subrectangular, separated by deep median cleft; terminal margins generally rounded, each with row of long spines interspersed with smaller spines and extending onto lateral margins, often with 1 or 2 submarginal rows of spinules on dorsal surface.

Color.-In life. Generally light reddish brown. Ocular peduncle with red blotch at base of cornea and red band proximally. Scutes on chelipeds sometimes with tinge of red. Stiff, iridescent setae on chelipeds and ambulatory pereopods.

Distribution.-Pacific coast of Japan from Sagami Bay to Kyushu, East China Sea; at depths of 90-338 m.

Remarks.-Doflein (1902) described Eupagurus lepidochirus on the basis of three specimens from Sagami Bay. He did not designate a holotype, and thus all three specimens are syntypes. However, only one of the three syntypes was located in the collection of the Zoologische Staatssammlung München._The whereabouts of the other two remain unknown. We are designating the Zoologische Staatssammlung München_female specimen as the lectotype of $E$. lepidochirus in the interest of nomenclatorial stability.

The lectotype is somewhat damaged: the antennular flagella are missing; both antennal acicles are broken off; short stiff setae arising from the scutes on the right palm are mostly missing; both second pereopods are missing.

With the invalidation of Eupagurus Brandt, 1851 (cf. Hemming, 1957, 1958) species assigned to that genus were returned to the genus Pagurus Fabricius, 1775. Reexamination of the female lectotype of $P$. lepidochirus revealed the presence of paired first pleopods modified as gonopods and other characters suggesting the reassignment of this species to either 

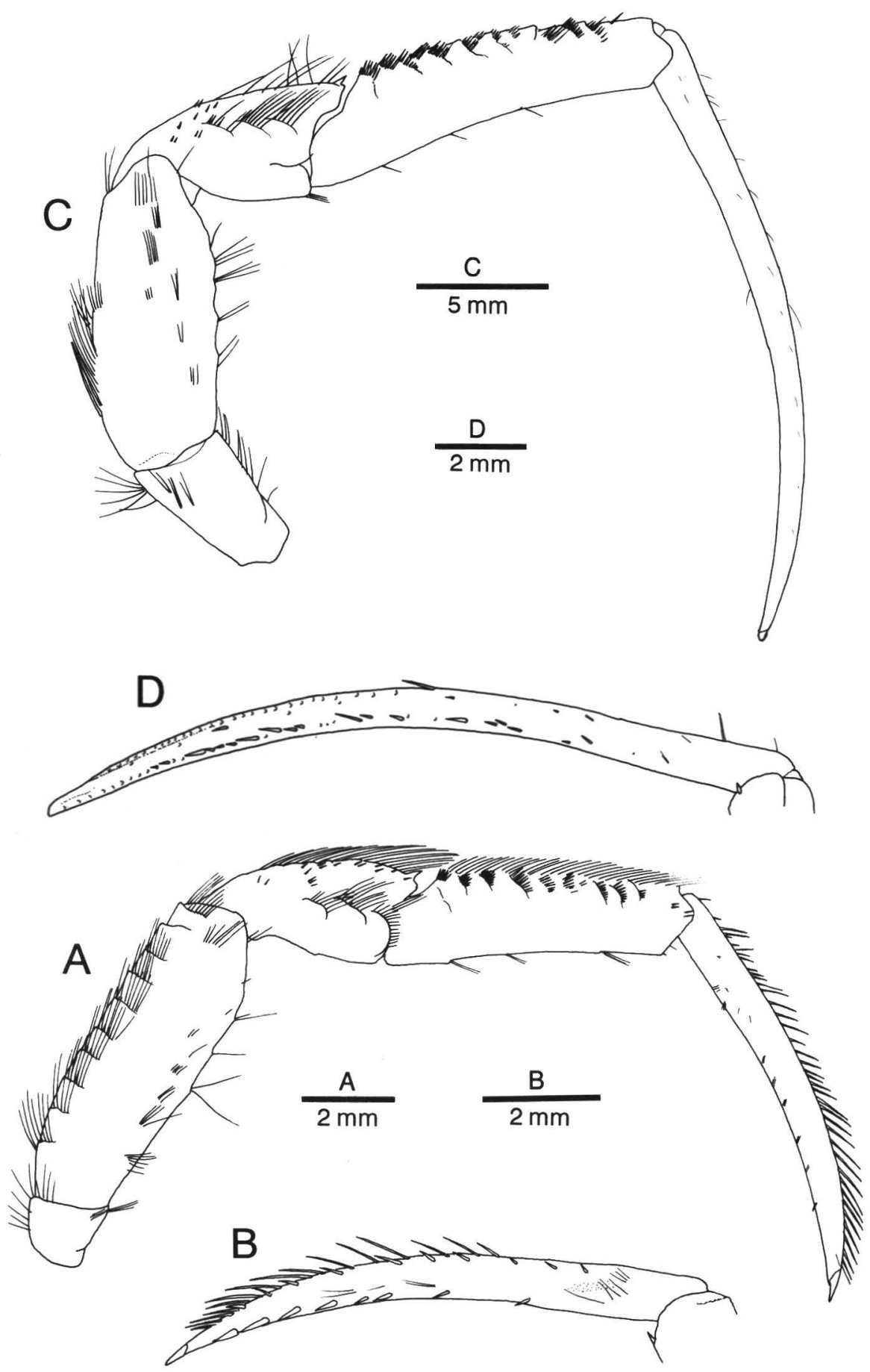

Fig. 4. Nematopagurus lepidochirus (Doflein, 1902), new combination. Ambulatory pereopods. A, B, female (sl $5.5 \mathrm{~mm}$ ) from Tosa Bay, CBM-ZC 3266; C, D, lectotype, female (sl $7.3 \mathrm{~mm}$ ) from Sagami Bay, ZSM 292/1. A, right second pereopod, lateral; B, dactylus of right second pereopod, mesial; C, right third pereopod, lateral, stiff setae partially missing; D, dactylus of right third pereopod, mesial, setae and corneous spines partially missing. 
Ceratopagurus or Nematopagurus. The latter characters include: 11 pairs of biserial phyllobranchiate gills; rostrum broadly rounded; ocular acicles very broadly separated; and chelipeds subequal in length. As previously noted, further examination of supplemental material revealed that males of Doflein's taxon had a long filamentous right sexual tube, thus requiring the reassignment of it to Nematopagurus. This species is identical with the species reported from Japanese waters under the name of $N$. squamichelis Alcock, 1905 (Miyake, 1978; 1982; 1991; 1999; Miyake \& Imafuku, 1980; Baba, 1986).

Nematopagurus squamichelis was originally described from the Andaman Sea, eastern Indian Ocean, based on a single female specimen. Although the holotype of $N$. squamichelis has not been available for study, topotypic specimens from the Nicobar Islands, eastern Indian Ocean, identified with Alcock's species by Balss (1912), have been reexamined (2 females, sl 4.7, $5.5 \mathrm{~mm}$, ZMB 16474, 18219). They agree well with the original description of $N$. squamichelis. Comparison of the Japanese material with the specimens from the Indian Ocean has shown that there are morphological differences that clearly distinguish the two taxa. The ocular peduncles are somewhat longer and the corneas more prominently dilated in $N$. squamichelis than in $N$. lepidochirus. The spines of the dorsomesial and dorsolateral margins of the right chela are appreciably stronger in the Indian Ocean species. More importantly, in N. squamichelis, the dorsal surfaces of the palms are nearly flat and the scutes are fewer in number, individually broader, and lack any suggestion of spination; the setae of the chelae and carpi lack iridescence. In contrast, the dorsal surfaces of the palms in $N$. lepidochirus are weakly convex; the scutes are not only shorter in individual breadth and more numerous, those in the midline most frequently are provided with a small spine, spinule or low tubercle, particularly on the left chela. The iridescence of the setae remains apparent after many years in preservative.

Nematopagurus chauseyensis McLaughlin, 1998 from Madagascar is morphologically even more similar to $N$. lepidochirus. Both species have more numerous and smaller scutes on the dorsal surfaces of the palms and carpi of the chelipeds. Although the presence of the row of spines on the dorsolateral margins of the chelae is useful in distinguishing $N$. lepidochirus from $N$. chauseyensis, the spines on the right chela are sometimes greatly reduced in large specimens of $N$. lepidochirus. The dorsal surfaces of the carpi of the second pereopods are each armed with one subproximal spine, in addition to the dorsodistal spine, in $N$. lepidochirus. The subproximal spines are absent in $N$. chauseyensis. The corneas are strongly dilated in both species, but they are more so in $N$. chauseyensis with corneal diameters often equaling or slightly exceeding the peduncular length. Additionally, the rostral lobe of $N$. chauseyensis is much more weakly developed, not approaching the level of the lateral projections, whereas the rostral lobe in $N$. lepidochirus is broadly rounded or roundly and obtusely subtriangular, and at least reaches the level of the lateral projections. Although the dactyli-propodi length ratios of the ambulatory legs are similar in both species, the dactyli of $N$. chauseyensis are actually longer given the overall sizes of the individuals.

All references to $P$. lepidochirus since Doflein's (1902) original description are simply literature citations. It is very probable that the reason the occurrence of Pagurus lepidochirus has not been recorded is that when found, the specimens have been incorrectly identified as $N$. squamichelis. From all information pres- 
ently available, Alcock's (1905) $N$. squamichelis is restricted in its distribution to the northern Indian Ocean.

\section{Acknowledgements}

The authors are indebted to $\mathrm{C}$. Oliver Coleman, Naturhistorisches Forschungsinstitut Museum für Naturkunde zu Berlin, Takeharu Kosuge, Ishigaki Tropical Station, Seikai National Fisheries Research Institute, Kunio Sasaki, Faculty of Science, Kochi University, Michael Türkay, Forschunginstitut Senckenberg, Frankfurt am Main, and Ryohei Yamanishi, Osaka Museum of Natural History, for loans or donation of specimens. We also thank Dr. Keiji Baba of Kumamoto University and an anonymous referee for reviewing the manuscript. The senior author thanks Hubert Fechter, Penerope Schneider and Eva Karl for their help and warm hospitality during his stay in Zoologische Staatssammlung München. This study was partially supported by Grant-in-Aid for International Scientific Research (No. 09041155) from the Japanese Ministry of Education, Science, Sports and Culture (Teruaki Nishikawa, principal investigator). This is a scientific contribution from the Shannon Point Marine Center, Western Washington University.

\section{Literature Cited}

Alcock, A., 1905. Anomura. Fasc. I. Pagurides. Catalogue of the Indian decapod Crustacea in the collection of the Indian Museum. $\mathrm{xi}+197 \mathrm{pp} ., 16 \mathrm{pls}$., Indian Museum, Calcutta.

Baba, K., 1986. Reptantia. In: Baba, K., Hayashi, K., \& Toriyama, M. (eds), Decapod crustaceans from continental shelf and slope around Japan. Japan Fisheries Resource Conservation Association, Tokyo, 148-231 (Japanese text and photographs), 279-316 (English text).

Balss, H., 1912. Paguriden. Wissenschaftliche Ergebnisse der deutschen Teefsee-Expedition "Valdivia" 1898-1899, 20: 85-124, pls 7-11.
Brandt, J. F., 1851. Krebse. In: Middendorff, A. Th. V. (ed.), Reise in den Äussersten Norden und Osten Sibiriens während der Jahre 1843 und 1844, 2 (Zoologie): 77-148.

Doflein, F., 1902. Ostasiatische Dekapoden. Abhandlungen der Bayerischen Akademie der Wissenschaften, München, 21: 613670 , pls 1-6.

Fabricius, J. C., 1775. Systema entomologiae, sistens Insectorum classes, ordines, genera, species, adjectis synonymis, locis, descriptionibus, observationibus. xxxii+832 pp., Officina Libraria Kortii, Flensburgi et Lipsiae.

Gordan, J., 1956. A bibliography of pagurid crabs, exclusive of Alcock, 1905. Bulletin of the American Museum of Natural History, 108: 253-352.

Hemming, F. (ed.), 1957. Opinion 472. Addition to the official list of generic names in zoology of the generic name Pagurus Fabricius, 1775, with Cancer bernhardus Linnaeus, 1758, as type species (Class Crustacea, Order Decapoda. Opinions and Declarations of the International Commission on Zoological Nomenclature, 16: 213276.

- 1958. Official index of rejected and invalid generic names in zoology, (1): i-xii, 1132. International Trust for Zoological Nomenclature, London.

Komai, T., 1999. Hermit crabs of the families Diogenidae and Paguridae (Crustacea: Decapoda: Anomura) collected during the Shin'yo-maru cruise to the Ogasawara Islands and Torishima Island, oceanic islands in Japan. Natural History Research, Special Issue 6: 1-66.

McLaughlin, P. A., 1974. The hermit crabs (Crustacea, Decapoda, Paguridea) of northwestern North America. Zoologische Verhandelingen, 130: 1-396, pl. 1.

- 1997. Crustacea Decapoda: Hermit crabs of the family Paguridae from the KARUBAR cruise in Indonesia. In: Crosnier, A. \& Bouchet, P., (ed.), R»sultats des campagnes MUSORSTOM, Volume 16. $\mathrm{M} »$ moires du Museum national d'Histoire naturelle, 172: 433-572.

-1998 . Hermit crabs of the genus Nematopagurus (Crustacea, Decapoda, Paguridae) from south-eastern South Africa and Madagascar: new records and new species. Zoosystema, 20: 315-338.

$\longrightarrow$, \& de Saint Laurent, M., 1998. A new genus for four species of hermit crabs formerly assigned to the genus Pagurus Fabricius (Decapoda: Anomura: Paguridae). 
Proceedings of the Biological Society of Washington, 111: 158-187.

\& Sandberg, L., 1995. Redescriptions of Gustaf Melin's press 1939 "Eupagurus (Pagurillus)" exiguus, "Eupagurus (Catapagurus)" vallatus, and "Eupagurus (Spiropagurus)" facetus (Decapoda: Anomura: Paguridae) based on the type material. Journal of Crustacean Biology, 15: 569-587.

Melin, G., 1939. Paguriden und Galatheiden von Prof. Dr. Sixten Bocks Expedition nach den Bonin-Inseln 1914. Kongliga Svenska Vetenskapsakademiens Handlinger, 18: 1119.

Milne-Edwards, A., \& Bouvier, E. L., 1892. Observation préliminaires sur les paguriens recueillis par les expéditions du Traveilleur et du Talisman. Annales des Sciences Naturelles, Zoologie et Paléontologie, série 7, 13: 185-226.

Miyake, S., 1978. The Crustacean Anomura of Sagami Bay. 200 pp., 4 pls., Biological Laboratory, Imperial Household, Tokyo. 1982. Japanese crustacean decapods and stomatopods in color. I. Macrura, Anomura and Stomatopoda. 261 pp., Hoikusha, Osaka. (In Japanese)

, 1991. Japanese crustacean decapods and stomatopods in color. I. Macrura, Anomura and Stomatopoda. Second printing. 261 pp., Hoikusha, Osaka. (In Japa- nese)

1999. Japanese crustacean decapods and stomatopods in color. I. Macrura, Anomura and Stomatopoda. Third printing. 261 pp., Hoikusha, Osaka. (In Japanese)

, \& Imafuku, M., 1980. Hermit crabs from Kii Peninsula. Nankiseibutu, 22: 5964. (In Japanese)

Terao, A., 1913. A catalogue of hermit-crabs found in Japan (Paguridae excluding Lithodidae), with descriptions of four new species. Annotationes Zoologicae Japonenses, 8: 355-391.

Yokoya, Y., 1933. On the distribution of decapod Crustacea inhabiting the continental shelf around Japan, chiefly based upon the materials collected by S.S. "Soyo Maru" during the years 1923-1930. Journal of the College of Agriculture Tokyo Imperial University, 12: 1-236.

Addressess: (TK) Natural History Museum and Institute, Chiba, 955-2 Aoba-cho, Chuoku, Chiba 260-8682, Japan. (PMcL) Shannon Point Marine Center, Western Washington University, 1900 Shannon Point Road, Anacortes, Washington 98221-9801B, U.S.A.

E-mails: (TK) komai@chiba-muse.or.jp; (PMcL) patsy@sos.net 